\title{
KINERJA PERTUMBUHAN DAN SINTASAN BENIH IKAN BAUNG (Hemibagrus nemurus) YANG DIBERI PROBIOTIK BERBEDA
}

\section{GROWTH PERFORMANCE AND SURVIVAL OF CATFISH (Hemibagrus nemurus) THAT WERE GIVEN THE DIFFERENT PROBIOTIC}

\author{
Adang Saputra ${ }^{1}$, Fia Sri Mumpuni ${ }^{2}$, Eri Setiadi $^{1}$, Irwan Dwi Setiawan ${ }^{3}$ \\ ${ }^{1}$ Peneliti pada Balai Riset Perikanan Budidaya Air Tawar dan Penyuluhan Perikanan \\ ${ }^{2}$ Staf Pengajar Program Studi Akuakultur Fakultuas Pertanian, Universitas Djuanda \\ ${ }^{3}$ Masiswa S1 Program Studi Akuakultur Fakultas Pertanian, Universitas Djuanda
}

Email: adang_pusrisdkp@yahoo.com

\begin{abstract}
Catfish (Hemibagrus nemurus) is a local fish which has a potential for culture, but the most high mortality occurres in larval stage. The water quality is one factor that causes high mortality. The purpose of this experiment is to evaluate the optimal growth and survival performances of catfish culture with probiotic application that containing Pseudomonas sp. and Bacillus sp. Fish test in this experiment was catfish with 21 of ages, $0.11 \pm 0.03 \mathrm{~g}$ in body weight and $2.04 \pm 0.30 \mathrm{~cm}$ in total length. Experimental design used complete randomize design consisted of three treatments and three replications for each treatment. The treatments were probiotic utility that containing i.e. A) without adding bacteria (control), B) adding Pseudomonas sp, and C) adding Bacillus sp. Fish culture was 60 days with feeding frequently three times a day (08:00; 14:00; and 20:00). Test paramaters were survival, length growth and weight growth, feeding conversion ratio, blood glucose, and water quality. The result of this experiment showed that the catfish with adding probiotic containing Pseudomonas sp can increase in survival $(82.1 \%)$, accelerate the length growth $(6.08 \mathrm{~cm})$ and weight absolute growth $(4.24 \mathrm{~g})$. Feed efficiency was 1.42 , no fish stress, and improved of water quality.
\end{abstract}

Key words: catfish fry, probiotic, growth, survival

\begin{abstract}
ABSTRAK
Ikan baung (Hemibagrus nemurus) merupakan ikan lokal yang mempunyai potensi untuk dijadikan komoditas ikan budidaya, namun tingkat kematian pada stadia benih masih tinggi. Salah satu faktor tingginya kematian benih adalah menurunnya kualitas air. Penelitian ini bertujuan untuk mengevaluasi kinerja pertumbuhan dan sintasan benih ikan baung terbaik yang dipelihara dengan aplikasi probiotik yang mengandung bakteri-bakteri jenis Pseudomonas sp. dan Bacillus sp. Ikan uji yang digunakan adalah ikan baung umur 21 hari dengan bobot rata-rata $0,11 \pm 0,03 \mathrm{~g}$ dan panjang total $2,04 \pm 0,30 \mathrm{~cm}$. Rancangan yang digunakan adalah rancangan acak lengkap dengan tiga perlakuan dan masing-masing diulang tiga kali. Perlakuan yang diberikan adalah penggunaan probiotik yang mengandung bakteri jenis: A. Tanpa pemberian bakteri (kontrol), B. Pseudomonas sp., dan C. Bacillus sp. Ikan uji dipelihara selama 60 hari dengan frekuensi pemberian pakan tiga kali sehari (jam 08.00, 14.00, dan 20.00 WIB). Parameter uji meliputi: sintasan, pertumbuhan panjang dan bobot mutlak, rasio konversi pakan, glukosa darah, dan kualitas air. Hasil penelitian menunjukkan bahwa benih ikan baung yang diberi probiotik yang mengandung bakteri jenis Pseudomonas sp. dapat meningkatkan sintasan $(82,1 \%)$, mempercepat pertumbuhan panjang dan bobot
\end{abstract}


mutlak $(6,08 \mathrm{~cm}$ dan 4,24 g), efisiesi penggunaan pakan $(1,42)$, tidak terindikasi stress dan mampu memperbaiki kualitas air.

Kata kunci: benih ikan baung, pertumbuhan, probiotik, sintasan

Adang Saputra, Fia Sri Mumpuni, Eri Setiadi. 2019. Kinerja Pertumbuhan dan Sintasan Benih Ikan Baung (Hemibagrus nemurus) yang diberi Probiotik Berbeda. Jurnal Mina Sains 5(1): $1-12$.

\section{PENDAHULUAN}

Ikan baung (Hemibagrus nemurus) merupakan ikan asli Indonesia (Gustiano et al. 2015) dan habitat alamiahnya diperairan tenang (Sukendi 2001). Ikan baung memiliki nilai ekonomis tinggi sebagai ikan konsumsi dalam bentuk segar maupun olahan. Hasil survai di Kabupaten Bogor tahun 2018 harga ikan baung ukuran konsumsi berkisar antara Rp.25.000,00-Rp.30.000,00/kg. Sampai saat ini, pemenuhan kebutuhan ikan baung ukuran konsumsi sebagian besar masih dipenuhi dari hasil tangkapan. Rendahnya penyedian ikan baung ukuran konsumsi dari hasil budidaya, karena penyediaan benihnya masih tebatas.

Kendala utama dalam pengembangan pembesaran ikan baung pada wadah terkontrol adalah terbatasnya pasokan benih secara kontinyu (Ali dan Juniarto 2014). Permasalahan yang dihadapi dalam pemeliharaan benih ikan baung pada wadah terkontrol adalah tingginya kematian. Penyebab tingginya kematian benih ikan baung diantaranya penyediaan air dengan kualitas yang tidak optimum (Suhenda et al. 2009; Rukmini 2012). Parameter kualitas yang dapat mematikan benih ikan baung adalah amonia (Rusmana 2003). Menurut Saputra et al. (2017) penyebab tingginya amonia dalam air adalah nitrogen. Salah satu upaya untuk mendegradasi nitrogen supaya tidak menjadi amonia yang melebihi batas ambang yang ditoleransi oleh ikan antara lain melalui aplikasi probiotik.

Probiotik merupakan suplementasi sel mikroba utuh atau komponen sel mikroba pada pakan atau lingkungan yang menguntungkan bagi inang (Feliatra et al. 2004; Irianto 2003). Penggunaan bakteri pendegradasi nitrogen pada budidaya ikan bertujuan untuk menjaga keseimbangan mikroba patogen dan memperbaiki kualitas air sebagai media budidaya (Gatesoupe 1999). Hasil penelitian Sya'bani et al. (2015), penggunaan probiotik yang berisi bakteri jenis Bacillus sp. dan Staphylococcus sp. pada budidaya ikan lele (Clarias sp.) dapat meningkatkan pertumbuhan dan sintasan. Menurut Yuriana et al. (2017), probiotik yang berisi bakteri jenis Bacillus sp. mempunyai kemampuan mengubah karbohidrat menjadi asam laktat dan meningkatkan sekresi enzim proteolitik (kecernaan pakan) di dalam usus. Menurut Wang et al. (2008) probiotik mempunyai kemampuan dalam memperbaiki kualitas air melalui penyeimbangan populasi mikroba, menurunkan patogennitas dan meningkatkan pertumbuhan. Purwanta dan Firdayati (2002), menyampaikan bahwa probiotik berperan sebagai dekomposer bahan organik menjadi mineral serta mengubah amonia dan nitrit yang bersifat racun menjadi senyawa nitrogen bebas melaui nitrifikasi dan detrinifikasi.

Jenis bakteri lain yang dapat digunakan sebagai agen bioremediasi yang ramah lingkungan untuk pengendalian amonia dan nitrit adalah Pseudomonas sp. Syahputra et al. (2011). Menurut Kumar et al. (2013) bakteri jenis Pseudomonas sp. merupakan bakteri dominan yang berperan sebagai bakteri nitrifikasi dan banyak 
digunakan sebagai probiotik untuk pengolahan air limbah dan perikanan, karena kemampuannya dalam mendegradasi nitrogen.

Tujuan penelitian ini adalah mengevaluasi kinerja pertumbuhan dan sintasan benih ikan baung terbaik yang dipelihara pada wadah terkontrol dengan aplikasi probiotik yang mengandung bakteri Pseudomonas sp. dan Bacillus sp.

\section{MATERI DAN METODE}

\section{Waktu dan Tempat}

Percobaan dilaksanakan pada bulan April-Mei 2018 bertempat di Instalasi Penelitian dan Pengembangan Teknologi Lingkungan dan Toksikologi Perikanan Budidaya Air Tawar. Balai Riset Perikanan Budidaya Air Tawar dan Penyuluhan Perikanan, Bogor, Jawa Barat.

\section{Alat dan Bahan}

Alat yang digunakan adalah bak fiber volume $500 \mathrm{~L}$ sebanyak sembilan buah untuk pemeliharaan ikan baung, aerator, baskom, centong, pipet, kertas label, saringan/seser, penggaris, dan timbangan digital dengan ketelitian dua desimal.

Bahan yang digunakan dalam penelitian ini adalah benih ikan baung dari hasil pemijahan secara buatan dari satu pasang induk berukuran rata-rata $750 \mathrm{~g}$. Benih ikan baung yang digunakan sebagai ikan uji berumur 21 hari dari menetas dengan bobot rata-rata $0,11 \pm 0,03 \mathrm{~g}$ dan panjang total $2,04 \pm 0,30 \mathrm{~cm}$. Pakan yang digunakan yaitu pakan komersial terapung dengan kandungan protein sekitar 39\%. Pakan diberikn secara at satiation. Probiotik yang diberikan sebagai perlakuan mengandung bakteri jenis Pseudomonas sp. dan Bacillus sp.

\section{Rancangan Percobaan}

Percobaan dirancang menggunakan rancangan acak lengkap (RAL) dengan 3 perlakuan, masing-masing perlakuan diulang 3 kali. Perlakuan yang diberikan adalah probiotik yang mengandung bakteri jenis:
A. Tanpa pemberian bakteri (kontrol);
B. Pseudomonas sp.; dan
C. Bacillus sp.

\section{Pemeliharaan Ikan Uji}

Pemeliharaan benih ikan baung dilakukan pada bak fiber dengan volume 500 L. Setiap wadah percobaan diisi air sebanyak 300 L. Masing-masing bak fiber dilengkapi dengan aerasi yang bersumber dari aerator untuk membantu mempertahankan oksigen di dalam air. Sebelum digunakan untuk pemeliharaan ikan uji, bak fiber terlebih dahulu dibersihkan dan didesinfektan menggunakan bayclin sebanyak $10 \mathrm{~mL}$. Setelah bak fiber bersih, selanjutnya diisi air dan didiamkan selama tiga hari. Setelah air berwarna kehijauan, wadah percobaan sudah siap ditambahkan probiotik. Pemberian probiotik dilakukan pada jam 10.00 WIB sebanyak $4 \mathrm{~mL} /$ wadah dan ulangan dilakukan setiap 10 hari pada waktu yang sama. Pembersihan kotoran pada wadah pemeliharaan, menggunakan teknik sipon yang dilakukan setiap dua hari sekali.

Setelah aplikasi probiotik selesai, selanjutnya benih ikan baung dimasukan secara acak kedalam wadah percobaan dengan kepadatan 1 ekor/L air. Selama pemeliharaan, ikan uji diberi pakan buatan komersial terapung sebanyak 5\% dari bobot biomasa. Waktu pemberian pakan yaitu jam 08.00 WIB, jam 14.00, dan jam 20.00 WIB. Penggantian air dilakukan untuk menambah valume air yang menyusut karena penguapan dan proses penyiponan.

\section{Parameter yang Diamati}

Data yang dicatat setiap hari adalah kematian ikan dan jumlah pakan. Data kematian digunakan untuk menghitung sintasan dan jumlah pakan digunakan untuk menghitung rasio konversi pakan yang dihitung pada akhir pemeliharaan. Sampling pertumbuhan dilakukan pada 
awal pemeliharaan, selanjutnya dilakukan setiap 10 hari sekali. Sebanyak 10 ekor dari masing-masing wadah diambil secara acak untuk keperluan pengukuran panjang total dan bobot individu. Pengukuran panjang total menggunakan penggaris dengan ketelitian $0,10 \mathrm{~cm}$ dan bobot individu menggunakan timbangan digital dengan ketelitian 0,01 g. Data panjang total dan bobot individu digunakan untuk menghitung panjang dan bobot mutlak pada akhir pemeliharaan. Penghitungan glukosa darah dilakukan melalui pengambilan sampel darah dari satu ekor benih ikan baung yang diambil secara acak pada setiap wadah percobaan. Pengambilan sampel darah menggunakan syringe volume $1 \mathrm{~mL}$. Data kualitas air diambil melalui pengukuran secra insitu setiap 10 hari sekali.

\section{Parameter Uji}

Parameter uji yang dihitung adalah sintasan dan rasio konversi pakan (Zonneveld et al. 1991), sedangkan parameter uji yang diukur adalah panjang dan bobot mutlak (Effendie 2002), pengukuran glukosa darah menggunakan blood glucose monotiring system dan kualitas air (suhu, pH, DO, dan amonia).

\section{Analisis Data}

Data yang diperoleh ditabulasi dan dihitung untuk keperluan analisis selanjutnya. Analisis sidik ragam (ANOVA) pada selang kepercayaan 95\%, digunakan untuk menentukan apakah perlakuan berbeda nyata terhadap sintasan, pertumbuhan panjang dan bobot mutlak, rasio konfersi pakan, serta glukosa darah. Apabila terdapat pengaruh nyata, maka dilanjutkan dengan uji Tukey untuk menentukan perbedaan antar perlakuan. Analisis deskriptif digunakan untuk menjelaskan parameter kualitas air yang ditampilkan dalam bentuk Tabel. Analisis data dilakukan dengan bantuan perangkat lunak Microsoft Office Excel 2010 dan SPSS 16.0.

\section{HASIL DAN PEMBAHASAN}

\section{Hasil}

\section{Sintasan benih ikan baung}

Sintasan benih ikan baung yang dipelihara tanpa aplikasi probiotik (kontrol) (A), dengan aplikasi probiotik yang mengandung bakteri jenis Pseudomonas sp. (B) dan Bacillus sp. (C), dihitung pada akhir pemeliharaan. Hasil perhitungan menunjukkan sintasan benih ikan baung berbeda secara nyata antar perlakuan $(\mathrm{P}<0,05)$. Hasil analisis statistik menunjukkan bahwa penggunaan probiotik yang mengandung bakteri Pseudomonas sp. berbeda secara nyata $(\mathrm{P}<0,05)$ dengan perlakuan A (kontrol) dan perlakuan $\mathrm{C}$ (Bacillus sp.). Namun perlakuan C (bakteri jenis Bacillus sp.) tidak berbeda nyata $(\mathrm{P}>0,05)$ dengan perlakuan A (kontrol) namun berbeda secara nyata dengan perlakuan B (Pseudomonas sp.). Sintasan tertinggi dicapai pada pemeliharaan benih ikan baung yang diberi probiotik dengan kandungan bakteri jenis Pseudomonas sp. mencapai $82,1 \pm 3,3 \%$ dan terendah pada perlakuan kontrol mencapai $60,1 \pm 9,7 \%$ (Gambar 1). Hasil ini menunjukkan bakteri jenis Pseudomonas sp. memberikan pengaruh terhadap peningkatan sintasan.

\section{Pertumbuhan panjang mutlak}

Hasil analisis statistik menunjukkan bahwa pertumbuhan panjang mutlak benih ikan baung tertinggi diperoleh pada pemeliharaan dengan aplikasi probiotik yang mengandung bakteri jenis Pseudomonas sp. mencapai $6,08 \mathrm{~cm}$ dan terendah pada perlakuak kontrol mencapai $4,56 \mathrm{~cm}$ (Tabel 1). Hasil perhitungan menunjukkan bahwa perlakuan B (bakteri jenis Pseudomonas sp.) berbeda secara nyata $(\mathrm{P}<0,05)$ dengan perlakuan $\mathrm{A}$ (kontrol) dan perlakuan C (Bacillus sp.), namun perlakuan $\mathrm{C}$ (Bacillus sp.) tidak berbeda nyata $(\mathrm{P}>0,05)$ dengan perlakuan $\mathrm{A}$ (kontrol). Hal ini menunjukkan bahwa bakteri jenis Pseudomonas sp. mempengaruhi terhadap peningkatan 
pertumbuhan panjang mutlak benih ikan baung.

\section{Pertumbuhan bobot mutlak}

Hasil analisis statistik menunjukkan bahwa pemberian probiotik yang mengandung bakteri jenis Pseudomonas sp. pada media pemeliharaan benih ikan baung memberikan pengaruh yang sangat nyata terhadap pertumbuhan bobot mutlak $(\mathrm{P}<0,05)$. Perhitungan terhadap bobot mutlak benih ikan baung tertinggi diperoleh pada pemeliharaan dengan aplikasi probiotik yang mengandung bakteri jenis Pseudomonas sp. mencapai 4,24g (Tabel 2). Hasil perhitungan menunjukkan bahwa perlakuan B (bakteri jenis Pseudomonas sp. tidak berbeda nyata $(\mathrm{P}>0,05)$ dengan perlakuan C (bakteri jenis Bacillus sp.), namun berbeda secara nyata $(\mathrm{P}<0,05)$ dengan kontrol. Hal ini menunjukkan bahwa bakteri jenis Pseudomonas sp. berpengaruh terhadap peningkatan pertumbuhan bobot mutlak benih ikan baung.

\section{Rasio konversi pakan}

Rasio konversi pakan benih ikan baung yang dipelihara dengan aplikasi probiotik yang mengandung bakteri jenis Pseudomonas sp. dan Bacillus sp. disajikan pada (Gambar 2). Hasil analisis statistik menunjukkan bahwa pemberian bakteri jenis Pseudomonas sp. memberikan pengaruh yang nyata terhadap konversi pakan benih ikan baung $(\mathrm{P}<0,05)$. Hasil perhitungan menunjukkan bahwa perlakuan B (bakteri jenis Pseudomonas sp.) tidak berbeda nyata $(\mathrm{P}>0,05)$ dengan perlakuan $\mathrm{C}$ (bakteri jenis Bacillus sp.), namun berbeda nyata $(\mathrm{P}<0,05)$ dengan perlakuan kontrol. Hasil ini menunjukkan bahwa rasio konversi pakan paling efisien pada pemeliharaan benih ikan baung dengan aplikasi probiotik yang mengandung bakteri jenis Pseudomonas sp.

\section{Glukosa darah}

Gambaran glukosa darah pada setiap perlakuan disajikan pada Gambar 3 . Penghitungan glukosa darah benih ikan baung yang dipelihara pada berbegai probiotik dilakukan pada akhir pemeliharaan. Hasil perhitungan terhadap glukosa darah berbeda secara nyata pada setiap perlakuan $(\mathrm{P}<0,05)$. Nilai glukosa darah terendah dicapai pada pemberian probiotik yang mengandung bakteri jenis Pseudomonas sp $(69,00 \pm 1,00 \mathrm{mg} / \mathrm{dL})$ dan terendah pada perlakuan kontrol $(89,33 \pm 1,53 \mathrm{mg} / \mathrm{dL})$. Hasil ini menunjukkan bahwa pemeliharaan benih ikan baung dengan aplikasi probiotik yang mengandung bakteri jenis Pseudomonas sp. tidak terindikasi mengalami stress, sehingga pertumbuhannya lebih baik.

\section{Kualitas air}

Parameter kualitas air yang diukur yaitu suhu $\left({ }^{0} \mathrm{C}\right), \mathrm{pH}, \mathrm{DO}$ (oksigen terlarut) dan amonia. Hasil pengukuran parameter kualitas air selama pemeliharaan berlangsung adalah: suhu berkisar antara 26,70-28,40 ${ }^{0} \mathrm{C}$, pH 7,02-8,66, DO 4,06$6,92 \mathrm{mg} / \mathrm{L}$, dan amonia 0,063-1,38 $\mathrm{mg} / \mathrm{L}$ pada seluruh perlakuan. Hasil pengukuran parameter kualitas air selama pemeliharaan benih ikan baung disajikan pada Tabel 3 .

\section{Pembahasan}

Berdasarkan hasil perhitungan terhadap sintasan benih ikan baung berkisar antara $60,1 \%-82,01 \%$. Sintasan tertinggi dicapai pada perlakuan B (bakteri jenis Pseudomonas sp.) yaitu $82,01 \%$ dan terendah dicapai pada perlakuan A (kontrol) sebesar 60,1 \%. Hasil ini menunjukkan pemberian probiotik yang mengandung bakteri Pseudomonas sp. berpengaruh secara nyata terhadap peningkatan sintasan ikan baung. Hal ini diduga Pseudomonas sp. berfungsi dengan baik, sehingga mampu memperbaiki kualitas air dan menekan bakteri yang tidak menguntukan bagi ikan. Menurut Syahputra et al. (2011); Kumar et al. (2013) bakteri Pseudomonas sp. 
merupakan bakteri yang dominan sebagai bakteri nitrifikasi dan paling banyak digunakan untuk pengolahan air limbah industri maupun perikanan. Menurut Patra et al. (2010), probiotik mempunyai kemampuan mendegradasi logam berat dan antibiotik, sehingga mampu meningkatkan sintasan ikan yang dipelihara.

Pemberian probiotik yang berisi bakteri jenis Pseudomonas sp. pada media pemeliharaan benih ikan baung memberikan pengaruh terhadap pertumbuhan panjang mutlak. Berdasarkan hasil perhitungan yang disajikan pada Tabel 1 menunjukkan pertumbuhan panjang mutlak benih ikan baung berkisar antara 4,56-6,08 cm. Kondisi ini menggambarkan Pseudomonas sp. mampu membuat media pemeliharaan menjadi lebih baik, sehingga ikan dapat tumbuh dan berkembang dengan baik. Kondisi ini sesuai dengan beberapa penelitian terkait diantaranya: Arief (2013) menggunakan probiotik sebanyak $5 \%$ pada ikan nila menghasilkan pertumbuhan panjang tertinggi sebesar $2,88 \%$, ikan nila merah yang diberi probiotik mendapatkan pertumbuhan yang tinggi sebesar $5,65 \mathrm{~cm}$ (Sumule et al. 2017), serta Noor dan Pakaya (2018), benih ikan gurame yang diberi probiotik Em4 dapat meningkatkan laju pertumbuhannya.

Pemberian probiotik pada media
pemeliharaan benih ikan baung memberikan efek terhadap pertambahan bobot mutlak. Berdasarkan hasil analisis, bobot mutlak (Tabel 2) yang diperoleh menunnjukkan hasil yang berbeda nyata $(\mathrm{P}<0,05)$. Hasil rataan bobot mutlak (Tabel 2) menunjukkan pertambahan bobot mutlak ikan baung berkisar 2,58-4,24 g, hal ini menunjukan bahwa nilai tertingi diperoleh pada aplikasi probiotik yang mengandung bakteri Pseudomonas sp. mencapai 4,24 g dan pertumbuhan terendah pada perlakuan tanpa probiotik (kontrol) mencapai 2,58 g. Menurut Sumule et al. (2017) penggunaan probiotik dapat memanfaatkan nutrisi secara maksimal dan meningkatkan metabolisme oleh bakteri probiotik yang dapat meningkatkan pertambahan bobot tertinggi sebesar 8,94 g.

Berdasarkan hasil perhitungan menunjukkan penggunaan probiotik berisi bakteri Pseudomonas sp. memberikan rasio konversi yang paling kecil $(1,42)$, sedangkan angka tertinggi $(4,56)$, dicapai pada pemeliharaan tanpa pemberian probiotik. Tingginya rasio konversi pakan pada pemeliharaan benih ikan baung tanpa aplikasi probiotik diduga tidak adanya bakteri yang dapat membantu proses degradasi senyawa organik pada media budidaya secara optimal. Menurut Effendi (2002) menyatakan bahwa semakin kecil konversi pakan maka semakin efektif pakan yang diberikan sehingga semakin tinggi nutrien termanfaatkan oleh ikan untuk pertumbuhan dan menurunkan sisa pakan ke lingkungan. Hasil penelitian Arief (2013) menunjukkan penembahan probiotik sebanyak $5 \%$ pada ikan nila memperoleh konversi pakan sebesar 54,69\%.

Tingginya kadar glukosa darah benih ikan baung yang dipelihara tanpa aplikasi probiotik diduga dalam kondisi stres karena mempertahankan kondisi tubuh terhadap media pemeliharaan. Kadar glukosa darah benih ikan baung paling kecil dicapai pada aplikasi probiotik yang mengandung bakteri jenis Pseudomonas sp. kondisi ini menggambarkan tingkat stres yang rendah. Ikan yang mengalami stres mengakibatkan hiperglisemia, yang dapat mengganggu perkembangan selanjutnya bahkan dapat mematikan (Hastuti et al. 2003). Glukosa darah merupakan gambaran dari respons stres sebagai akibat dari pelepasan hormone kortisol di hipotalamus melalui aliran darah menuju hati untuk merombak glikogen menjadi glukosa, sehingga glukosa darah menjadi meningkat (Porchase et al. 2009).

Kualitas air mempunyai peranan penting untuk menunjang pertumbuhan dan sintasan benih ikan baung. Penurunan kualitas air dalam proses pemeliharaan ikan dapat mengakibatkan kematian, terhambatnya pertumbuhan, wabah 
penyakit dan tingginya rasio konversi pakan. Menurut Erdiansyah et al. (2014) menyatakan bahwa kualitas air merupakan faktor utama dalam mendukung kehidupan dan pertumbuhan ikan yang di tentukan oleh faktor kimia dan faktor fisika air diantaranya suhu, $\mathrm{pH}, \mathrm{DO}$, dan amonia.

Berdasarkan hasil pengukuran kualitas air pada pemeliharaan benih ikan baung yang diberi probiotik dengan kandungan jenis bekteri berbeda disajikan pada Tabel 3. Hasil pengukuran terhadap suhu air selama pemeliharaan benih ikan baung yang diberi probiotik berbeda berkisar antara $26,70-28,40{ }^{\circ} \mathrm{C}$. Kondisi ini masih optimum untuk partumbuhan dan perkembangan benih ikan baung. Hasil pengukuran terhadap konsentrasi $\mathrm{pH}$ air berkisar antara 7,02-8,66. Kondisi ini masih optimum untuk pemeliharaan benih ikan banung. Kisaran optimum untuk pemeliharan ikan menurut Oliveira et al. (2012); Courtenay dan Williams 2004) adalah 4,25-9,4. Hasil ini juga sesuai hasil penelitian Ali dan Junianto (2014), benih ikan baung dapat tumbuh dengan baik pada kisaran $\mathrm{pH}$ 6-9. Kandungan oksigen terlarut (DO) selama penelitian pada perlakuan tanpa probiotik berkisar antara 4,06-6,92 mg/L, pada aplikasi probiotik dengan kandungan bekteri jenis Pseudomonas sp. berkisar antara 5,09-6,92 mg/L. Menurut Salmin (2005), kisaran DO tersebut masih aman bagi benih ikan baung, karena benih ikan baung dapat hidup pada perairan rendah oksigen.

Selanjutnya nilai amonia selama masa pemeliharaan 60 hari menunjukkan perbedaan antar perlakuan. Kandungan amonia relatif paling rendah dicapai pada aplikasi probiotk dengan kandungan bakteri jenis Pseudomonas sp. beriksar antara 0,01-0,15 mg/L. Pada konsentrasi tinggi, amonia dapat menjadi toksik bagi ikan karena mengganggu proses pengikatan oksigen oleh darah. Menurut Minggawati (2012), amonia dapat meningkat akibat sisa pakan dan kotoran yang mengendap serta bangkai ikan yang mati pada media pemeliharaan. Melalui aplikasi probiotik dengan kandungan bakteri jenis Pseudomonas sp. mampu mempertahankan konsentasi amonia masih dalam kondisi yang optimum untuk benih ikan baung. Menurut standar baku kualitas air kelas II PP No. 82 tahun 2001, konsentrasi amonia $\leq 0,02 \mathrm{mg} / \mathrm{L}$.

\section{KESIMPULAN DAN IMPLIKASI}

Berdasarkan hasil penelitian menunjuk-kan penggunaan probiotik yang berisi bakteri jenis Pseudomonas sp. mampu meningkatkan kinerja pertumbuhan dan sintasan terbaik benih ikan baung yang dipelohara pada wadah terkontrol.

Hasil penelitian ini merupakan informasi dasar untuk meningkatkan produktivitas pada pemeliharaan benih ikan baung secara terkontrol harus menggunakan probiotik yang berisi bakteri Pseudomonas sp.

\section{UCAPAN TERIMA KASIH}

Ucapan terima kasih kami sampaikan kepada Balai Riset Penelitian Budidaya Air Tawar dan Penyuluhan, Bogor yang telah mendanai penelitian ini melalui APBN 2018. Ucapan terima kasih kami sampaikan kepada, Dr. Ani Widiyati dan Muhamad Rizki Maulana yang telah memberikan masukan, koreksi dan bantuan teknis dalam penyelesaian karya tulis ini.

\section{DAFTAR PUSTAKA}

Ali M, SR Juniarto. 2014. Pengaruh lanjutan suhu pada penetasan telur terhadap pertumbuhan dan kelangsungan hidup benih ikan baung Hemibagrus nemurus. Prosiding Seminar Nasional Lahan Suboptimal. Palembang, Indonesia: hlm 301-308.

Arief M. 2013. Pemberian probiotik yang berbeda pada pakan komersial terhadap pertumbuhan retensi protein dan serat kasar pada ikan nila Oreochromis nilloticus. Agroveteriner 1: 88-98. 
Courtenay WR, JD Williams. 2004. Snakehead Pisces, Channidae: A Biological Synopsis and Risk Assesment, US Geological Survei, US Geological Survei Cirkular, Denver, Colo, USA.

\section{Effendi MI. 2002. Biologi Perikanan. Yogyakarta: Yayasan Pustaka Nusantara.}

Erdiansyah M, EI Raharjo, Sunarto. 2014. Pengaruh persentase pergantian air yang berbeda terhadap kelangsungan hidup dan pertumbuhan benih ikan baung Hemibagrus nemurus. Jurnal Ruaya 3: 21-25.

Feliatra E, Irwan, S Edwar. 2004. Isolasi dan identifikasi bakteri probiotik ikan kerapu macan Ephinephelus fuscogatus dalam upaya efisiensi pakan. Jurnal Natur Indonesia 6: 7580 .

Gatesoupe FI. 1999. The use of probiotics in aquaculture. Aquaculture. 180: 147-165.

Gustiano R, II Kusmini, MHF Ath-thar. 2015. Mengenal Sumber Daya Genetik Ikan Spesifik Lokal Air Tawar Indonesia Untuk Pengembangan Budidaya. Bogor: IPB Press.

Hardjamulia A, N Suhenda. 2000. Evaluasi sifat reproduksi dan sifat gelondongan generasi pertama empat strain ikan baung Mystus nemurus di karamba jaring apung. Jurnal Penelitian Perikanan Indonesi. 6: 24-35.

Hastuti S, E Supriyono, I Mokoginta, Subandiyono. 2003. Respon glukosa darah ikan gurami Osphronemus gourami, LAC. Terhadap stres perubahan suhu lingkungan. Jurnal Akuakultur Indonesia 2: 73-77.
Kinerja Pertumbuhan dan Sintasan Benih Ikan Baung

Irianto A. 2003. Probiotik Akuakultur. Yogyakarta : Gadjah Mada University Press.

Kottelat, Maurice, Kartikasari, Nuraini S. 1993. Ikan air tawar Indonesia Bagian Barat dan Sulawesi. Jakarta: Kantor Menteri Negara Kependudukan dan Lingkungan Hidup RI.

Kumar VJR, V Sukumaran, C Achuthan, V Joseph, R Philip, SB Singh. 2013. Molecular characterization of the nitrifying bacterial consortia employed for the activation of bioreactors used in brackish and marine aquaculture systems. International Biodeteration and Biodegradation 78: 74-81.

Minggawati I, Saptono. 2012. Parameter kualitas air untuk budidaya ikan patin Pangasius pangasius di karamba sungai Kahayan, Kota Palangka Raya. Jurnal Imu Hewani Tropika 13: $27-$ 32.

Noor SY, R Pakaya. 2018. Pengaruh penambahan probiotik Em4 (evective mikroorganisme 4) dalam pakan terhadap pertumbuhan dan kelangsungan hidup ikan gurame Osprhronemus gouramy. Jurnal Fisheries 1: 107-112.

Oliveira EG, AB Pinheiro, VQ Oliveira, AR Junior, MG Moraes, IR Rocha, RR Sousa, FH Costa. 2012. Effect of stocking density on the performance of juvenile pirarucu Arapaima gigas in cages. Aquaculture 370: 96-101.

Patra S, SC Ghosh, D Sarkar, BB Jana. 2010. Cadmium tolerance and antibiotic resistance of Psedumonas sp. Isolated from water, sludges, and fish raised in wastewater-fedtropical ponds. Indian Jurnal Experimental Biology 48: 383-393. 
Porchase MM, R Luis, C Martinez, R Enriquez, Rogelo. 2009. Cortisol and glucose: reliable indicators of fish stress. American Journal of Aquatic Science 4: 158-178.

PPRI (Peraturan Pemerintah RI) No. 82 Tahun 2001. Standar Baku Mutu Air untuk Budidaya Perairan. Republik Indonesia

Purwanta W, M Firdayati. 2002. Pengaruh aplikasi mikroba probiotik pada kuaitas kimiawi perairan tambak udang. Jurnal Teknologi Lingkungan 3: 61-65.

Rukmini. 2012. Teknologi Budidaya Air. Bandung: Karya Putra Darwati.

Rusmana I. 2003. Nitrous oxide formation in bacteria. Jurnal Mikrobiologi Indonesia 8: 63-66.

Salmin. 2005. Oksigen terlarut dan kebutuhan oksigen biologi sebagai salah satu indikator untuk menentukan kualitas perairan. Jurnal Oseana 30: 21-26.

Saputra A, L Setianingsih, Yosmaniar, TH Prihadi. 2017. Distribusi nitrogen dan fosfor pada budidaya ikan gabus Channa striata dan probiotik. Jurnal Riset Akuakultur 12: 379-388.

Steel RGD, JH Torrie. 1981. Principles and Procedur of Statistic, Biometrical Aprroach. Kogakushi: Mc Graw Hill.

Suhenda N, R Samsudin, J Subagja. 2009. Peningkatan produksi benih ikan baung Mystus nemurus melalui kadar lemak pakan induk. Jurnal Ilmu-Ilmu Hayati 9: 539-546.

Sukendi. 2001. Biologi reproduksi dan pengendaliannya dalam upaya pembenihan ikan baung Hemibagrus nemurus diperairan sungai Kampar, Riau. [Disertasi]. Bogor : Institut Pertanian Bogor.
Sumule JF, DT Tobigo, Rusaini. 2017. Aplikasi probiotik pada media pemeliharaan terhadap pertumbuhan dan sintasan ikan nila merah Oerochromis sp. Jurnal Agrisains 18: $1-12$.

Sya'bani N, A Yustiati, I Rustikawati, AM Lusiastuti. 2015. Frekuensi penambahan probiotik Bacillus sp. dan Staphylococus sp. pada media pemeliharaan benih ikan lele dumbo Clarias gariepinus untuk ketahanan terhadap Aeromonas hydrophila. Jurnal Kelautan Perikanan 7: 130 140.

Syahputra K, I Rusmana, U Widiyastuti. 2011. Isolasi dan karakterisasi bakteri denitrifikasi sebagai agen bioromediasi nitrogen anorganik. Jurnal Riset Akuakultur 6: 197-209.

Wang YB, JR Li, J Lin. 2008. Probiotics in aquaculture: Challenges and outlook. Aquaculture 281: 1-4.

Yuriana L, H Santoso dan A Sutanto. 2017. Pengaruh strain Lactobacillus terhadap pertumbuhan dan efisiensi pakan lele masamo Clarias sp. terhadap pendederan ikan dengan sistem bioflok sebagai sumber biologi. Jurnal Lentera Pendidikan Pusat Penelitian LPPM UM METRO 2: 13-23.

Zonneveld N, EA Huisman, JH Boon. 1991. Prinsip-prinsip budidaya ikan. Jakarta: PT. Gramedia Pustaka Utama. 
Tabel 1. Panjang mutlak benih ikan baung yang diberi berbagai probiotik selama 60 hari masa pemeliharaan

\begin{tabular}{cccc}
\hline \multirow{2}{*}{ Ulangan } & \multicolumn{3}{c}{ Panjang mutlak $(\mathrm{cm})$} \\
\cline { 2 - 4 } & $\begin{array}{c}\text { A. Tanpa bakteri } \\
\text { (Kontrol) }\end{array}$ & $\begin{array}{c}\text { B. Bakteri jenis } \\
\text { Pseudomonas } \mathrm{sp} .\end{array}$ & $\begin{array}{c}\text { C. Bakteri jenis } \\
\text { Bacillus } \text { sp. }\end{array}$ \\
\hline 1 & 4,58 & 5,87 & 5,25 \\
2 & 4,26 & 6,88 & 5,34 \\
3 & 4,83 & 5,48 & 5,49 \\
\hline $\begin{array}{c}\text { Rata-rata panjang } \\
\text { mutlak (cm) }\end{array}$ & $4,56 \pm 0,28^{\mathrm{a}}$ & $6,08 \pm 0,73^{\mathrm{b}}$ & $5,36 \pm 0,12^{\mathrm{a}}$ \\
\hline Keterangan : Superskip dengan huruf yang berbeda pada tabel menunjukkan hasil yang berbeda nyata $(P$ \\
$<0,05)$
\end{tabular}

Tabel 2. Bobot mutlak benih ikan baung yang diberi berbagai probiotik selama 60 hari masa pemeliharaan

\begin{tabular}{|c|c|c|c|c|}
\hline \multirow{2}{*}{\multicolumn{2}{|c|}{ Ulangan }} & \multicolumn{3}{|c|}{ Bobot mutlak (g) } \\
\hline & & $\begin{array}{l}\text { A. Tanpa bakteri } \\
\text { (Kontrol) }\end{array}$ & $\begin{array}{l}\text { B. Bakteri jenis } \\
\text { Pseudomonas sp. }\end{array}$ & $\begin{array}{l}\text { C. Bakteri jenis } \\
\text { Bacillus sp. }\end{array}$ \\
\hline \multicolumn{2}{|l|}{1} & 2,72 & 4,04 & 3,52 \\
\hline \multicolumn{2}{|l|}{2} & 2,27 & 4,89 & 3,19 \\
\hline \multicolumn{2}{|l|}{3} & 2,76 & 4,13 & 3,62 \\
\hline \multicolumn{2}{|c|}{$\begin{array}{l}\text { Rata-rata bobot } \\
\text { mutlak }(\mathrm{g})\end{array}$} & $2,58 \pm 0,27^{\mathrm{a}}$ & $4,24 \pm 0,47^{b}$ & $3,44 \pm 0,23^{b}$ \\
\hline \multicolumn{5}{|c|}{$\begin{array}{l}\text { Keterangan :Superskrip dengan huruf yang berbeda pada tabel menunjukkan hasil yang berbeda nyata }(P \\
<0,05)\end{array}$} \\
\hline \multicolumn{5}{|c|}{$\begin{array}{l}\text { Tabel 3. Parameter kualitas air pada pemeliharaan benih ikan baung yang diberi berbagai } \\
\text { probiotik selama } 60 \text { hari masa pemeliharaan }\end{array}$} \\
\hline \multirow{2}{*}{ Parameter } & \multicolumn{4}{|c|}{ Probiotik (bakteri jenis) } \\
\hline & A. & apa bakteri (Kontrol) & B. Pseudomonas sp. & C. Bacillus sp. \\
\hline Suhu $\left({ }^{0} \mathrm{C}\right)$ & & $26,90-28,20$ & $26,90-28,10$ & $26,70-28,40$ \\
\hline \multicolumn{2}{|l|}{$\mathrm{pH}$} & $7,36-8,61$ & $7,02-8,43$ & $7,38-8,66$ \\
\hline \multicolumn{2}{|l|}{$\mathrm{DO}(\mathrm{mg} / \mathrm{L})$} & $4,06-6,42$ & $5,05-6,92$ & $4,95-6,25$ \\
\hline \multicolumn{2}{|l|}{$\begin{array}{l}\text { Amonia } \\
(\mathrm{mg} / \mathrm{L})\end{array}$} & $0,01-0,20$ & $0,01-0,15$ & $0,01-0,22$ \\
\hline
\end{tabular}




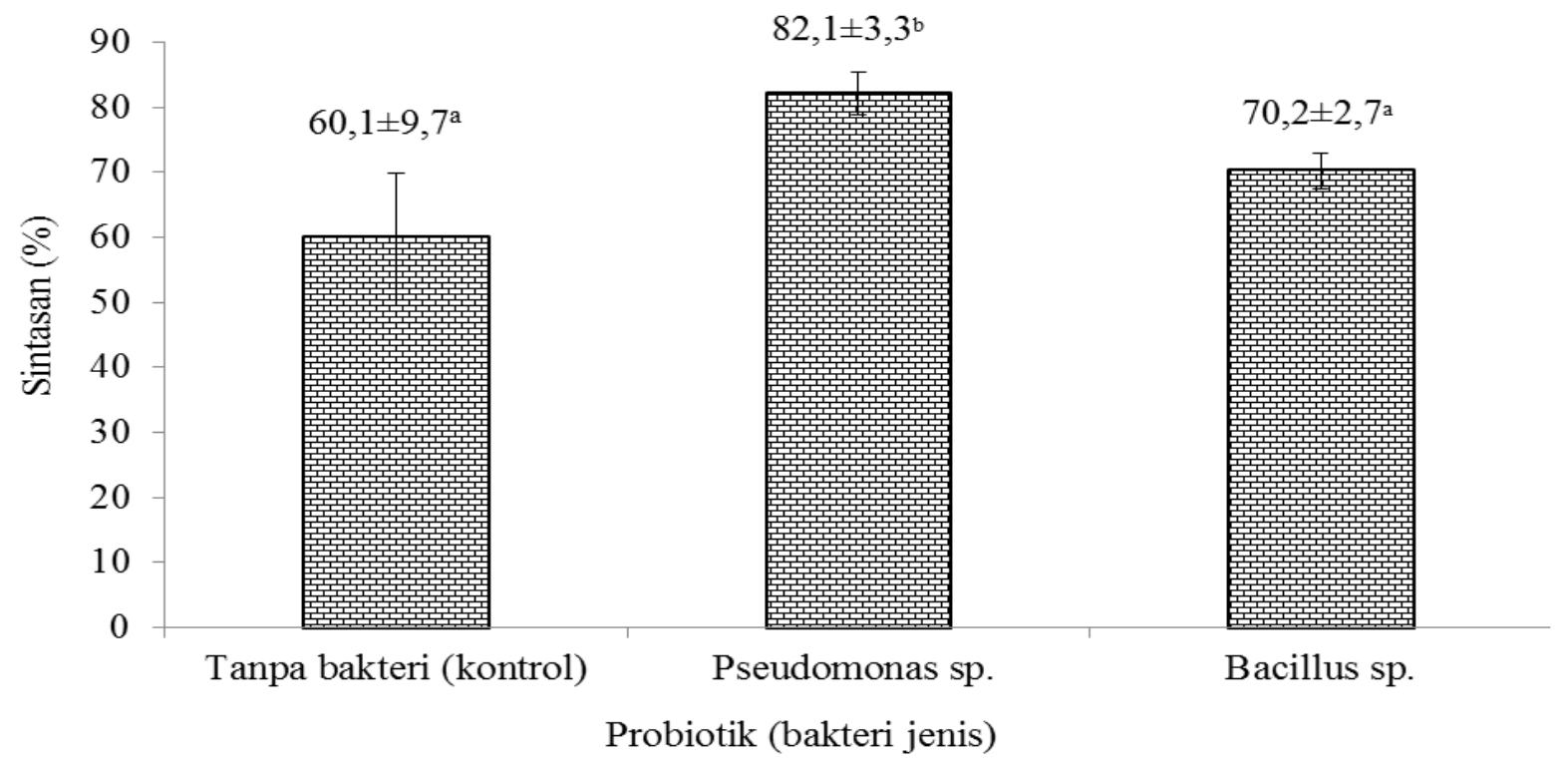

Keterangan : Superskip dengan huruf yang berbeda pada gambar menunjukkan hasil yang berbeda nyata (P $<0,05)$.

Gambar 1. Sintasan benih ikan baung yang diberi berbagai probiotik selama 60 hari masa pemeliharaan

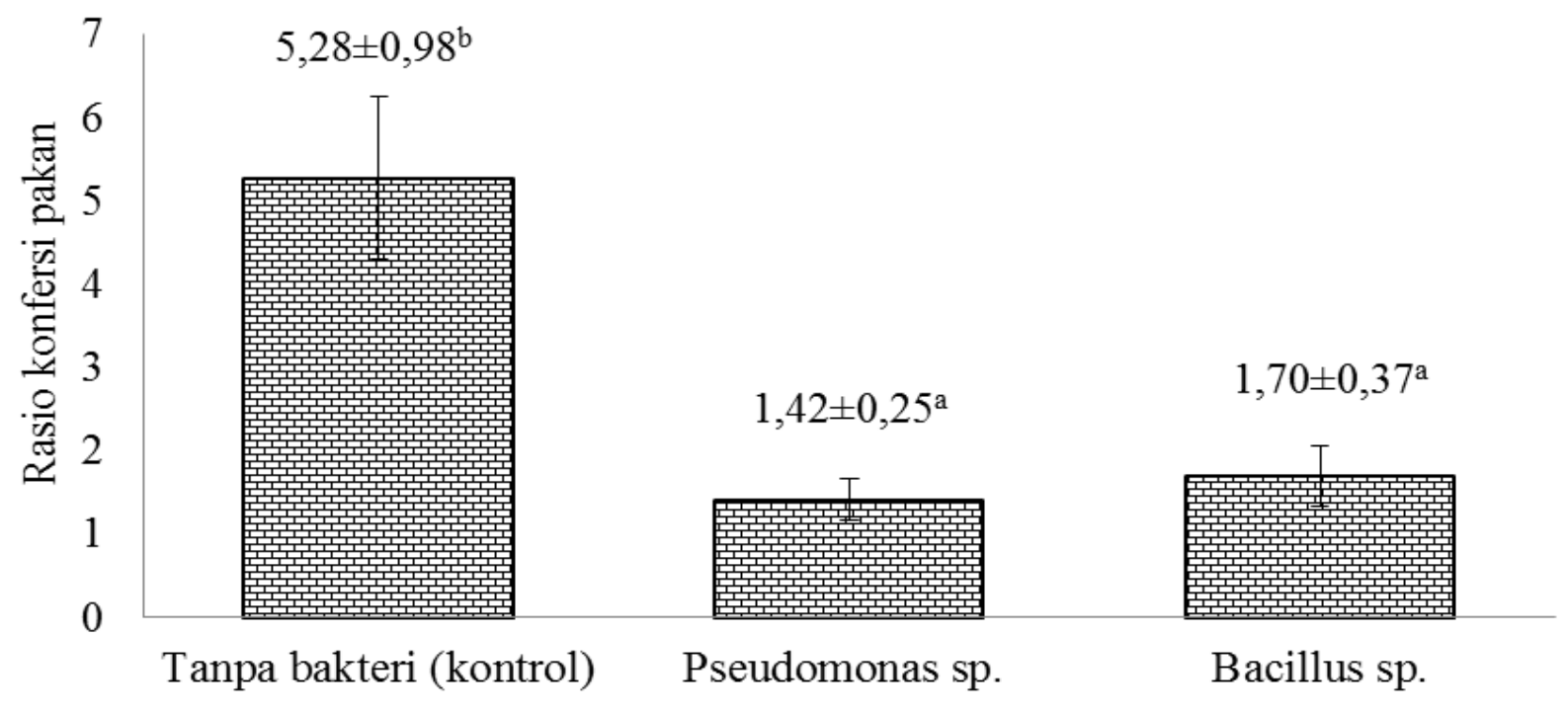

\section{Probiotik (bakteri jenis)}

Keterangan : Superskip dengan huruf yang berbeda pada gambar menunjukkan hasil yang berbeda nyata $(P$ $<0,05)$

Gambar 2. Rasio konversi pakan pada benih ikan baung yang diberi berbagai probiotik selama 60 hari masa pemeliharaan 


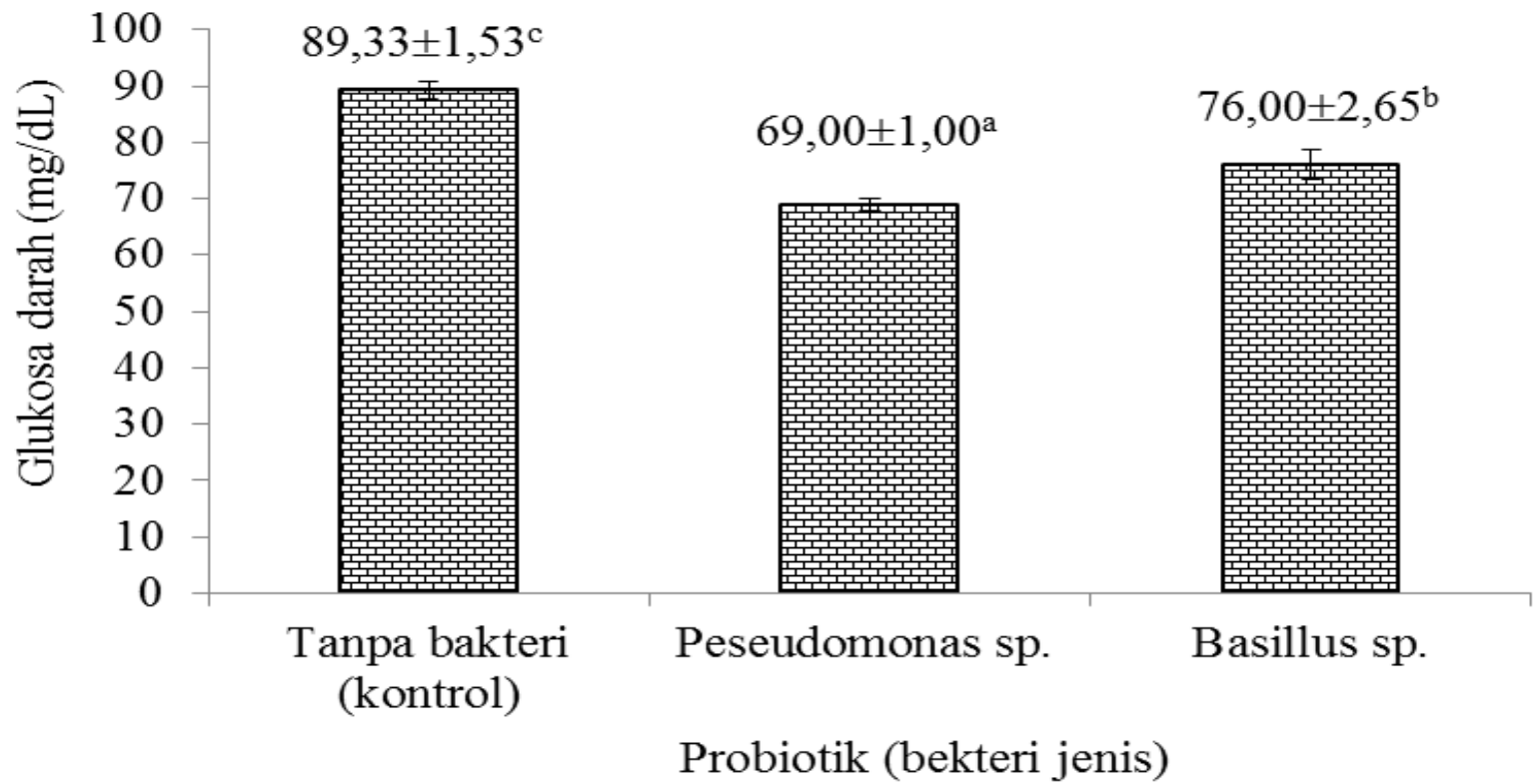

Keterangan : Superskip dengan huruf yang berbeda pada gambar menunjukkan hasil yang berbeda nyata $(P$ $<0,05)$

Gambar 3. Glukosa darah benih ikan baung yang diberi berbagai probiotik selama 60 hari masa pemeliharaan 